\title{
MACRO NUTRIENTS UPTAKE OF FORAGE GRASSES AT DIFFERENT SALINITY STRESSES
}

\author{
F. Kusmiyati, E.D. Purbajanti and B.A. Kristanto \\ Faculty of Animal Agriculture, Diponegoro University, \\ Tembalang Campus, Semarang 50275, Central Java - Indonesia \\ Corresponding E-mail : fkusmiyati@yahoo.co.id
}

Received June 30, 2009; Accepted August 7, 2009

\begin{abstract}
The high concentration of sodium chloride $(\mathrm{NaCl})$ in saline soils has negative effects on the growth of most plants. The experiment was designed to evaluate macro nutrient uptake (Nitrogen, Phosphorus and Potassium) of forage grasses at different $\mathrm{NaCl}$ concentrations in growth media. The experiment was conducted in a greenhouse at Forage Crops Laboratory of Animal Agriculture Faculty, Diponegoro University. Split plot design was used to arrange the experiment. The main plot was forage grasses (Elephant grass (Pennisetum purpureum ) and King grass (Pennisetum hybrida)). The sub plot was $\mathrm{NaCl}$ concentration in growth media $(0,150$, and $300 \mathrm{mM})$. The nitrogen $(\mathrm{N})$, phosphorus $(\mathrm{P})$ and potassium $(\mathrm{K})$ uptake in shoot and root of plant were measured. The result indicated increasing $\mathrm{NaCl}$ concentration in growth media significantly decreased the N, P and K uptake in root and shoot of the elephant grass and king grass. The percentage reduction percentage of $\mathrm{N}, \mathrm{P}$ and $\mathrm{K}$ uptake at $150 \mathrm{mM}$ and $300 \mathrm{mM}$ were high in elephant grass and king grass. It can be concluded that based on nitrogen, phosphorus and potassium uptake, elephant grass and king grass are not tolerant to strong and very strong saline soil.
\end{abstract}

Keywords : nitrogen uptake, phosphorus uptake, potassium uptake, salinity, forage grasses

\section{INTRODUCTION}

Land use for forage crops moves towards marginal soil such as saline soil. Saline soil at Java and Sumatra is approximately 400.000 ha mostly widespread at north Java and east Sumatra (Partohardjono and Syam, 1992). Soil utilization of saline soil for agriculture faces many obstacles. The most important problem of saline soil is the high concentration of soluble salts (especially $\mathrm{NaCl}$ and $\mathrm{Na}_{2} \mathrm{SO}_{4}$ ) that has negative effects on the growth of most plants. Salinity is the concentration of dissolved minerals salts present in water and soils on a unit volume or weight basis (Majerus, 1996).

Abrol et al. (1988) classify soil salinity based on conductivity (EC/Electrical Conductivity) and its effect on crop growth. There are 5 classes: (1) non saline soil with conductivity of $0-2 \mathrm{dS} / \mathrm{m}$, salinity effects are negligible, (2) slightly saline soil with conductivity of 2-4 dS/m, yields of sensitive crops may be restricted, (3) moderately saline soil with conductivity of 4-8 dS/m, yields of many crops are restricted, (4) strongly saline soil with conductivity of 8-16 dS/m, only tolerant crops yield satisfactorily, and (5) very strongly saline soil with conductivity of more than $16 \mathrm{dS} / \mathrm{m}$, only a few very tolerant crops yield satisfactorily.

The effect of salinity on plant growth is very complex.. Salinity imposes an ionic stress, an osmotic stress and secondary stresses such as nutritional disorders and an oxidative stress. The high osmotic pressure in saline solutions hampers plant water uptake, resulting in physiological drought. (Flowers, 1977). Sodium $\left(\mathrm{Na}^{+}\right)$excess in soil particles causes expansion and soil pore closing that aggravate gas transfer with in disperse soil colloid materials (Sipayung, 2003). Excessive sodium ions at the root surface may disrupt plant potassium uptake that is vital for the maintenance of cell turgor, membrane potential and the activity of many enzymes (Xiong and Zhu, 2002). Leaves of crops growing in saline soil may be smaller and darker blue green in color 
than the normal leaves. Increased succulence often results from salinity. Plants in saline soil often have the same appearance as plants growing under moisture stress (drought) conditions, although the wilting of plants is far less prevalent (Abrol et al., 1988).

Salt stress studies generally have been done in liquid media with complete nutrient solution (Sopandie, 1990). The advantage of using liquid media is easy to maintain the salt concentrations during the research. The salt concentrations are also more precise according to the treatment.

The essential nutrients for crops are sixteen elements that are absorbed from the air and soil. The nutrients that are absorbed from soil can be divided into two classes : macro nutrients and micro nutrients. The macro nutrients are nitrogen $(\mathrm{N})$, Phosphorus (P), Potassium (K) Calcium (Ca), Magnesium (Mg) and Sulphur (S). The crops need huge amounts of macro nutrient for their normal growth (Hakim et al., 1986).

The experiment was designed to evaluate macro nutrient uptake (Nitrogen, Phosphorus and Potassium) of forage grasses at different $\mathrm{NaCl}$ concentrations in growth media. The obtained results can contribute to better knowledge on forage crop cultivation in saline soil especially about macro nutrient uptake.

\section{MATERIALS AND METHODS}

The research was carried out at Forage Crops Laboratory, Animal Agriculture Faculty of Diponegoro University. Split plot design was used to arrange the experiment. The main plot was forage grasses (Elephant grass (Pennisetum purpureum )and King Grass (Pennisetum hybrida)). The sub plot was $\mathrm{NaCl}$ concentration in growth media $(0,150$, and 300 $\mathrm{mM})$. There were 3 replications.

Stem cutting were planted in pots containing sand and compost with comparison of 3: 1. The grasses were cut at four weeks after planting in order to have the same initial growth. Then, the seedlings were transplanted into pots containing complete nutrient solution based on that used by Sopandie (1990).. The complete nutrient solution consists of: $\mathrm{Ca}\left(\mathrm{NO}_{3}\right)$. $4 \mathrm{H}_{2} \mathrm{O} 1.0 \mathrm{mM} ; \mathrm{KNO}_{3} 4.0 \mathrm{mM} ; \mathrm{NH}_{4} \mathrm{NO}_{3} 0.5 \mathrm{mM}$; $\mathrm{KH}_{2} \mathrm{PO}_{4} 1.0 \mathrm{mM} ; \mathrm{MgSO}_{4} .7 \mathrm{H}_{2} \mathrm{O} 1.0 \mathrm{mM}$;
$\mathrm{MnSO}_{4} \cdot \mathrm{H} 2 \mathrm{O} 0.05 \mathrm{ppm} ; \mathrm{CuSO}_{4} .5 \mathrm{H}_{2} \mathrm{O} 0.02 \mathrm{ppm}$; $\mathrm{ZnSO}_{4} .7 \mathrm{H}_{2} \mathrm{O} 0.05 \mathrm{mM} ; \mathrm{H}_{3} \mathrm{BO}_{3} 0.5 \mathrm{ppm}$ and $\mathrm{Fe}-$ EDTA $0.034 \mathrm{mM}$. $\mathrm{NaCl}$ was added to nutrient solution based on the treatments. The nutrient solution was aerated continuously and renewed once a week.

The grasses were cut at six weeks after transplanted to the nutrient solution. The nitrogen $(\mathrm{N})$, phosphorus $(\mathrm{P})$ and potassium $(\mathrm{K})$ uptakes in shoot and root of plant were measured. Nitrogen was analyzed by Kjedahl's method (AOAC, 1975). Phosphorus was analyzed by spectrophotometer methods (Sulaiman et al., 2005) and Potassium was analyzed by flamefotometry method (Sulaiman et al., 2005). The N, P and K uptake in shoot and root were calculated using the following formula :

$\mathrm{N}$ uptake in shoot or root $=\% \mathrm{~N}$ x Dry matter of shoot or root

$\mathrm{P}$ uptake in shoot or root $=\% \mathrm{P} \times$ Dry matter of shoot or root

$\mathrm{K}$ uptake in shoot or root $=\% \mathrm{~K} \times$ Dry matter of shoot or root

The results were analyzed using analysis of variance, then were followed by Duncan Multiple Range Test (Steel and Torrie, 1980).

\section{RESULTS AND DISCUSSION}

The electrical conductivity at $0 \mathrm{mM}, 150 \mathrm{mM}$ and $300 \mathrm{mM}$ were equivalent to $0 \mathrm{dS} / \mathrm{m}, 13.7 \mathrm{dS} / \mathrm{m}$ and $27.4 \mathrm{dS} / \mathrm{m}$, respectively. The salinity of $\mathrm{NaCl}$ concentration in this research can be classified as non saline $(0 \mathrm{mM})$, strongly saline $(150 \mathrm{mM})$ and very strongly saline (300 mM) (Abrol et al, 1988).

\section{Nitrogen (N) Uptake}

Based on the analysis of variance, concentration of $\mathrm{NaCl}$ affected $\mathrm{N}$ uptake in shoot and root significantly $(\mathrm{P}<0.05)$. There were statistical differences of nitrogen $(\mathrm{N})$ uptake in root between the elephant grass and the king grass. It can be seen in Table 1, Duncan's test showed that increasing the $\mathrm{NaCl}$ concentration in growth media decreased $\mathrm{N}$ uptake in shoot and root significantly $(\mathrm{P}<0.05)$. Nitrogen uptake either on shoot or root of elephant grass and king grass at $\mathrm{NaCl} 150 \mathrm{mM}$ and $300 \mathrm{mM}$ significantly lower than at $0 \mathrm{mM}$.

Crop absorbs nitrogen in the form of nitrate $\left(\mathrm{NO}_{3}\right)$ and Ammonium $\left(\mathrm{NH}_{4}^{+}\right)$. Increasing $\mathrm{NaCl}$ from 0 
Table 1. Nitrogen Uptake (mg/pot) in Root and Shoot of Elephant Grass and King Grass at Different Concentration of $\mathrm{NaCl}$

\begin{tabular}{lcccccc}
\hline \multirow{2}{*}{$\begin{array}{l}\mathrm{NaCl} \\
\text { concentration }\end{array}$} & \multicolumn{3}{c}{ Nuptake in root } & \multicolumn{3}{c}{ Nuptake in shoot } \\
\cline { 2 - 7 } & $\begin{array}{c}\text { Elephant } \\
\text { grass }\end{array}$ & King grass & Mean & $\begin{array}{c}\text { Elephant } \\
\text { grass }\end{array}$ & King grass & Mean \\
\hline $0 \mathrm{mM}$ & $193.2^{\mathrm{b}}$ & $357.9^{\mathrm{a}}$ & $275.5^{\mathrm{a}}$ & $1512.8^{\mathrm{b}}$ & $3035.6^{\mathrm{a}}$ & $2274.2^{\mathrm{a}}$ \\
$150 \mathrm{mM}$ & $87.9^{\mathrm{d}}$ & $123.2^{\mathrm{c}}$ & $105.6^{\mathrm{b}}$ & $508.4^{\mathrm{d}}$ & $852.0^{\mathrm{c}}$ & $680.2^{\mathrm{b}}$ \\
$300 \mathrm{mM}$ & $61.5^{\mathrm{e}}$ & $62.6^{\mathrm{e}}$ & $62.1^{\mathrm{c}}$ & $333.0^{\mathrm{d}}$ & $381.4^{\mathrm{d}}$ & $357.2^{\mathrm{b}}$ \\
\hline Mean & $114.2^{\mathrm{b}}$ & $181.2^{\mathrm{a}}$ & & 784,7 & 1423.0 & \\
\hline
\end{tabular}

Different superscript in the mean coloumn or row at the same parameter indicated statistically significant differences $(\mathrm{P}<0.05)$

Different superscript in the same coloumn and row at the same parameter indicated statistically significant differences $(\mathrm{P}<0.05)$

$\mathrm{mM}$ to $300 \mathrm{mM}$ resulted in the decline of $\mathrm{N}$ uptake in shoot and root of grasses. High salinity affects nitrate uptake at two levels : by direct competition of nitrate and chloride $\left(\mathrm{Cl}^{-}\right)$and at the membrane level and/or the membrane proteins by changing plasma lemma integrity (Cramer et al., 1985). Saline condition can influence the different steps of $\mathrm{N}$ metabolism such as uptake, reduction and protein synthesis (Frechill, 2001). Several biochemical processes are affected by salinity, particularly nitrate assimilation. Nitrate is the most significant source of nitrogen for plants and frequently limits plant growth. Nitrate uptake and nitrate reductase activity (NRA) decrease in plants under salt stress. The addition of $600 \mathrm{mmol} . \mathrm{L}^{-1} \mathrm{NaCl}$ induced a substantial decline in NRA by about $64 \%$ in roots and 52\% in leaves (Meloni et al., 2004). High salinity also will decrease the nitrification rate (Firestone, 1985).

In order for ions/nutrients to be absorbed by plant roots, they must come in contact with the root surface. There are generally three ways in which this contact is affected. These are contact exchange, diffusion of ions in the soil solution and movement of ions by mass flow of water in the soil. Movement of ions in the soil solution to the surface of roots is an important factor in ion uptake. This movement is accomplished largely by diffusion and mass flow. Mass flow refers to the movement of water together with dissolved electrolytes (ions) through the soil. This movement occurs as a result of rainfall or irrigation but more importantly as a result of the diffusion pressure gradient set up by water absorption by plant roots. Nitrate move to the root surface mainly by mass flow
(Tisdale and Nelson, 1975). The primary effect of excess salinity is that it renders less water available to plant (Orak and Ates, 2005). This is because the osmotic pressure of the soil solution increases as the salt concentration increases (Bazzigaluppi et al., 2008). The osmotic pressure at $150 \mathrm{mM}$ and 300 $\mathrm{mM} \mathrm{NaCl}$ were equivalent to 4,932 and 9,864 bars, respectively. Less water available for plant will also reduce the $\mathrm{N}$ uptake of plant. High salinity also caused plasmolysis. Plasmolysis will make the root riot so it decreases the ability for absorbing water and nutrient.

Leaves of elephant grass and king grass at 150 $\mathrm{mM}$ and $300 \mathrm{mM} \mathrm{NaCl}$ were yellowing or chlorosis. This appearance showed that the grasses were deficient in nitrogen. Research by Huffaker and Rains (1985) showed that the growth of barley at saline soil was inhibited because the low uptake of nitrate and ammonium. At the $\mathrm{NaCl}$ concentration below $100 \mathrm{mM}$, the nutrient uptake of barley was not significantly affected. The nitrate uptake at $\mathrm{NaCl}$ $200 \mathrm{mM}$ was $17 \%$ from control $(0 \mathrm{mM} \mathrm{NaCl})$, while ammonium uptake was $38 \%$.

The research on saline soil in Semarang showed that $\mathrm{N}$ fertilizer of $250 \mathrm{~kg} \mathrm{~N} / \mathrm{ha}$ produced $28 \%$ higher dry matter yield of elephant grass than $\mathrm{N}$ fertilizer of $150 \mathrm{~kg} \mathrm{~N} / \mathrm{ha}$ (Kusmiyati et al., 2001). Manure fertilizer and bed type also affect the growth and dry matter yield of elephant grass in saline soil in Semarang. Manure fertilizer equal to $150 \mathrm{~kg} \mathrm{~N} / \mathrm{ha}$ and bed type resulted high dry matter yield of elephant grass. Manure fertilizer and bed type also decreased the Na content in saline soil (Kusmiyati et al., 2002). 
The reduction of $\mathrm{N}$ uptake in elephant grass shoot ranged from $66.4 \%$ to $77.9 \%$, while in root ranged from $54.5 \%$ to $68.2 \%$. Nitrogen uptake reduction in king grass also high. It ranged from $65.6 \%$ to $82.5 \%$ in shoot and $71.9 \%$ to $87.4 \%$ in root (Table 1). The result showed that elephant grass and king grass are not tolerant to strongly and very strongly saline soil.

\section{Phosphorus (P) Uptake}

Phosphorus uptake in shoot and root of grasses at $150 \mathrm{mM}$ and $300 \mathrm{mM} \mathrm{NaCl}$ significantly lower than at $0 \mathrm{mM}$ (Table 2). In Elephant grass, $\mathrm{P}$ uptake in shoot and root at $150 \mathrm{mM} \mathrm{NaCl}$ was not significantly different from that at $300 \mathrm{mM}$. While in king grass, there was significant difference of $\mathrm{P}$ uptake at 150 $\mathrm{mM}$ and $300 \mathrm{mM}$ (Table 2).

Phosphorus, nitrogen and potassium, is classified as a major nutrient element. It is generally considered that plants absorb most of their phosphorus as the primary orthophosphate ion $\left(\mathrm{H}_{2} \mathrm{PO}^{-}\right)$. Phosphorus uptake is affected by the $\mathrm{pH}$ of the medium surrounding the roots. Lower $\mathrm{pH}$ values will increase the absorption of the $\mathrm{H}_{2} \mathrm{PO}^{-}$ion, whereas, higher $\mathrm{pH}$ values will increase absorption of the $\mathrm{HPO}_{4}{ }^{2-}$ form. In most soils, phosphorus availability is at a maximum in the $\mathrm{pH}$ range from 5.5 to 7.0 , the availabity decrease as the $\mathrm{pH}$ drops below 5.5 and also decreases as this values goes above 7.0. Above $\mathrm{pH} 7.0$, the ions of calcium and magnesium cause precipitation of the added phosphorus and its availability decreases (Tisdale and Nelson, 1975). pH of saline soil was around 8.5 , the phosphorus availability was low, and so the P uptake was low.

Phosphorus moves from soil to roots by ion diffusion process. Plant absorb $\mathrm{P}$ by contact exchange (Tisdale and Nelson, 1975). Salinity affects water and air movement, water holding capacity and root penetration (Qadir et al., 2008). The inhibited water and air movement in saline soil cause the low movement of $\mathrm{P}$ from soils to roots, finally the absorption decreases. The low water holding capacity and root penetration also cause decreasing of $\mathrm{P}$ uptake by root plant.

Phosphorus affects the root growth of plant, cell differentiation, involved in photosynthesis, assimilation and respiration process (Lakitan, 2000). The low uptake of $\mathrm{P}$ will cause the inhibition all those process, so that the plant growth decrease.

The reduction of $\mathrm{P}$ uptake in elephant grass root ranged from $56.8 \%$ to $57.8 \%$, while in shoot ranged from $64.7 \%$ to $68.9 \%$. Phosphorus uptake reduction in king grass also high. It ranged from $63.2 \%$ to $86.4 \%$ in shoot and $38.6 \%$ to $82.8 \%$ in root (Table 2). The result showed that elephant grass and king grass are not tolerant to strongly and very strongly saline soil.

\section{Potassium (K) Uptake}

Potassium uptake in shoot and root of grasses at $150 \mathrm{mM}$ and $300 \mathrm{mM}$ significantly lower than at 0 $\mathrm{mM}$. In Elephant grass, $\mathrm{K}$ uptake in shoot and root at $150 \mathrm{mM}$ was not significantly different from that at $300 \mathrm{mM}$. While in king grass, there was significant

Table 2. Phosphorus Uptake (mg/pot) in Root and Shoot of Elephant Grass and King Grass at Different Concentrantion of $\mathrm{NaCl}$

\begin{tabular}{lcccccc}
\hline \multirow{2}{*}{$\begin{array}{l}\mathrm{NaCl} \\
\text { concentration }\end{array}$} & \multicolumn{3}{c}{ P uptake in root } & \multicolumn{3}{c}{ P uptake in shoot } \\
\cline { 2 - 7 } & $\begin{array}{c}\text { Elephant } \\
\text { grass }\end{array}$ & King grass & Mean & $\begin{array}{c}\text { Elephant } \\
\text { grass }\end{array}$ & King grass & Mean \\
\hline $0 \mathrm{mM}$ & $325.4^{\mathrm{ab}}$ & $553.5^{\mathrm{a}}$ & $439.5^{\mathrm{a}}$ & $591.6^{\mathrm{b}}$ & $1137.4^{\mathrm{a}}$ & $864.5^{\mathrm{a}}$ \\
$150 \mathrm{mM}$ & $140.6^{\mathrm{c}}$ & $339.9^{\mathrm{b}}$ & $240.3^{\mathrm{ab}}$ & $208.6^{\mathrm{d}}$ & $418.0^{\mathrm{c}}$ & $313.3^{\mathrm{b}}$ \\
$300 \mathrm{mM}$ & $137.4^{\mathrm{c}}$ & $95.2^{\mathrm{d}}$ & $116.3^{\mathrm{b}}$ & $184.2^{\text {de }}$ & $154.8^{\mathrm{e}}$ & $169.5^{\mathrm{c}}$ \\
\hline Mean & 201.1 & 329,5 & & 328.1 & 570.1 &
\end{tabular}

Different superscript in the mean coloumn or row at the same parameter indicated statistically significant differences $(\mathrm{P}<0.05)$

Different superscript in the same coloumn and row at the same parameter indicated statistically significant differences $(\mathrm{P}<0.05)$ 
difference of K uptake at $150 \mathrm{mM}$ and $300 \mathrm{mM}$ (Table $3)$.

Potassium reaches the root surface by ion diffusion. As a plant root absorbs nutrients from the surrounding soil solution, a diffusion gradient is set up. This gradient result in the continuous movement of additional ions to the root surface and their absorption by plant (Tisdale and Nelson, 1975). High salinity at growth media cause excessive sodium $(\mathrm{Na})$ ions at the root surface. Sodium at high concentration has a strong inhibitory effect on potassium uptake by root (Xiong and Zhu, 2002). Sodium ions are not required for the plant growth (Tisdale and Nelson, 1975). At high salinity, plant will absorb sodium instead of potassium. Sodium, once enter the cytoplasm has strong inhibitory effect on the activity of many enzymes. (Xiong and Zhu, 2002). Low K uptake will reduce the plant growth. Potassium involved in physiological functions such as carbohydrate metabolism or formation and breakdown and translocation of starch, nitrogen metabolism and synthesis of proteins, control and regulation of activities of various essential mineral elements, activation of various enzymes and adjustment of stomata movement and water relation (Tisdale and Nelson, 1975).

The reduction of $\mathrm{K}$ uptake in elephant grass root ranged from $47.8 \%$ to $53.8 \%$, while in shoot ranged from $74.1 \%$ to $75.3 \%$. Potassium uptake reduction in king grass also high. It ranged from $71.8 \%$ to $80.1 \%$ in shoot and $73.1 \%$ to $81.9 \%$ in root. The result showed that elephant grass and king grass are not tolerant to strongly and very strongly saline soil.
These results were in accordance with Neto et al. (2004). They reported high Na concentration on corn that is planted at $\mathrm{NaCl} 100 \mathrm{mM}$. Potassium uptake decrease as much as $36 \%$ at $\mathrm{NaCl} 100 \mathrm{mM}$. Wang et al. (2002) concluded that elephant grass is sensitive plant to high salinity. The dry matter yield decreased $50 \%$ at EC $25 \mathrm{dS} / \mathrm{m}$.

\section{CONCLUSION}

It could be concluded that the nitrogen, phosphorus and potassium uptake in elephant grass and king grass decrease at $\mathrm{NaCl}$ concentrations of $150 \mathrm{mM}$ and 300 $\mathrm{mM}$. Based on nitrogen, phosphorus and potassium uptake, elephant grass and king grass are not tolerant to strongly and very strongly saline soil.

\section{ACKNOWLEDGEMENT}

This publication is part of research that was funded by A3 Competition Grant of Nutrition and Feed Department, Faculty of Animal Agriculture, Diponegoro University. We thanks Retno Widiyawati for her help during the research.

\section{REFERENCES}

Abrol, I.P., J.S.V. Yadav and F.I. Massaud. 1988. Salt-Affected Soil and Their Management. FAO, Rome.

AOAC. 1975. Official Methods of Analyis. $12^{\text {th }} \mathrm{Ed}$. Association of Official Analytical Chemists. Washington DC., USA.

Table 3. Pottasium Uptake (mg/pot) in Root and Shoot of Elephant Grass and King Grass at Different Concentrantion of $\mathrm{NaCl}$

\begin{tabular}{lcccccc}
\hline \multirow{2}{*}{\begin{tabular}{l}
$\mathrm{NaCl}$ concentration \\
\cline { 2 - 7 }
\end{tabular}} & $\begin{array}{c}\text { Elephant } \\
\text { grass }\end{array}$ & King grass & Mean & $\begin{array}{c}\text { Elephant } \\
\text { grass }\end{array}$ & King grass & Mean \\
\hline $0 \mathrm{mM}$ & $90.3^{\mathrm{b}}$ & $265.4^{\mathrm{a}}$ & $177.9^{\mathrm{a}}$ & $1873.2^{\mathrm{b}}$ & $3289.1^{\mathrm{a}}$ & $2581.2^{\mathrm{a}}$ \\
$150 \mathrm{mM}$ & $47.1^{\mathrm{c}}$ & $71.5^{\mathrm{b}}$ & $59.3^{\mathrm{b}}$ & $485.4^{\mathrm{d}}$ & $933.3^{\mathrm{c}}$ & $709.35^{\mathrm{b}}$ \\
$300 \mathrm{mM}$ & $41.7^{\mathrm{c}}$ & $47.9^{\mathrm{c}}$ & $44.8^{\mathrm{b}}$ & $463.1^{\mathrm{de}}$ & $653.1^{\mathrm{e}}$ & $558.1^{\mathrm{b}}$ \\
\hline Mean & 59.7 & 128.3 & & $940.6^{\mathrm{b}}$ & $1625.2^{\mathrm{a}}$ &
\end{tabular}

Different superscript in the mean coloumn or row at the same parameter indicated statistically significant differences $(\mathrm{P}<0.05)$

Different superscript in the same coloumn and row at the same parameter indicated statistically significant differences $(\mathrm{P}<0.05)$ 
Bazzigalupi, O., S.M. Pistorale and A.H. Andres. 2008. Salinity tolerance during seed germination from naturalized populations of tall wheatgrass (Thiropyrum ponticum). Cien. E. Inv. Agr. 35 (3) : 231-238

Cramer GR, A. Läuchli and V.S. Polito. 1985. Displacement of $\mathrm{Ca}^{2+}$ by $\mathrm{Na}^{+}$from the plasmalemma of root cells. A primary response to salt stress?. Plant Physiol. 79:207-277

Firestone, M. K. 1985. Microbial nutrient transformations in saline soils and adaptations of microorganisms to soil salinity In : Soil and Plant Interactions with Salinity. Agricultural Experiment Station, Univ of California.

Flowers, T.J., P.F. Troke and A.R. Yeo. 1977. The mechanism of salt tolerance in halophytes. Annual Rev. Plant. Physiol. 28 : 89-121.

Frechill. S, B. Lasa, L. Ibarretxe, C. Lamsfus and A.Trejo. 2001. Pea responses to saline stress are affected by the source of nitrogen nutrition (ammonium or nitrate). Plant Growth Regul. 35:171-179.

Hakim, N., Y. Nyakpa, A. M., Lubis, S. G. Nugroho, R. Saul., A. Diha., G. B. Hong and H. H. Bailey. 1986. Dasar-dasar Ilmu Tanah. Penerbit Universitas Lampung.

Huffaker, R. C. and D. W. Rains. 1985. N use efficiency as influenced by $S$ assimilation in barley exposed to salinity. In : Soil Plant Interactions with Salinity. Agricultural Experiment Station, University of California.

Kusmiyati, F., E. D. Purbajanti dan W. Slamet. 2001. Pengaruh pemupukan kalsium dan nitrogen terhadap produksi dan kualitas hijauan rumput pakan pada tanah salin. Jurnal Pengembangan Peternakan Tropis, Special Edition Oktober 2001.

Kusmiyati, F., R. T. Mulatsih dan A. Darmawati. 2002. Pengaruh pengguludan dan pupuk kandang terhadap pertumbuhan dan produksi hijauan rumput pakan pada tanah salin. Jurnal LitBang Propinsi Jawa Tengah 1:46-52

Lakitan, B. 2000. Dasar-dasar Fisiologi Tumbuhan, PT. Raja Grafindo Persada, Jakarta.

Majerus, M. 1996. Plant Materials for Saline-Alkaline Soils. USDA Natural Resources Conservation Services, Montana State University.
Meloni, D.A., M.R. Gulotta, C.A. Martinez and M.A. Olivia. 2004. The effects of salt stress on growth, nitrate reduction, proline and glycinebetaine accumulation in Presopis alba. Braz. J. Plant Physiol. 16 (1) : 1-7

Neto, A.D., J.T. Prisco, J. Eneas-Ftho, C.F. Lacerda, J.V. Silva, P.H.A. da Costa and E. GomezFilho.2004. Effects of salt stress on plant growth, stomata response and solute accumulation of different maize genotype. Braz. J. Plant Physiol. $16(1): 8-16$

Orak, A. and E. Ates. 2005. Resistance to salinity stress and available water levels at the seedling stage of common vetch (Vicia sativa L.). Plant Soil Environt. 51 (2) : 51-56

Partohardjono, S. dan R. M. Syam. 1992. Pengembangan Terpadu Pertanian Lahan Rawa Pasang Surut dan Lebak. PPPTP, BPPP Departemen Pertanian, Jakarta.

Qadir, M., A. Tubeileh, J. Akhtar, A. Larbi, P.S. Minhas and M. A. Khan. 2008. Productivity enhancement of salt-affcted environments through crop diversification. Land Degrad. Develop. $19: 429-453$

Sipayung, R. 2003. Stres Garam dan Mekanisme Toleransi Tanaman. USU digital libarry, Medan.

Sopandie, D. 1990. Studies on Plant Responses to Salt Stress. Dissertation Ph. D. Okayama University, Japan.

Steel, R.G.D. dan J.H. Torrie. 1980. Principle and Procedure of Statistics. McGrow-Hill Book Company.

Sulaiman, Suparto dan Eviati, 2005. Analisis Kimia Tanah, Tanaman, Air dan Pupuk. Balai Penelitian Tanah, Bogor.

Tisdale S.L. and W.L. Nelson. 1975. Soil Fertility and Fertilizers. Macmillan Publ. Co. Inc. New York.

Wang, D. J.A. Poss, T.J. Donovan, M.C. Shannon and S.M. Lesch. 2002, Biophysical properties and biomass production of elephant grass under saline conditions. J. Arid Env. 52 (4) : 447 - 456.

Xiong, L and J.K. Zhu. 2002. Salt Tolerance in the Arabidopsis Book. Am. Society of Plant Biologists. Pp. 1-24 